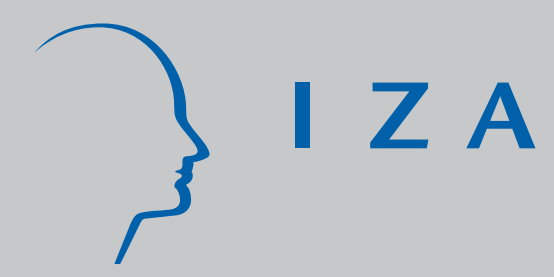

IZADP No. 2402

Do the Unemployed Become Successful

Entrepreneurs? A Comparison between the Unemployed, Inactive and Wage-Earners

Pernilla Andersson

Eskil Wadensjö

October 2006 


\title{
Do the Unemployed Become Successful Entrepreneurs? A Comparison between the Unemployed, Inactive and Wage-Earners
}

\author{
Pernilla Andersson \\ SOFI, Stockholm University, SULCIS \\ Eskil Wadensjö \\ SOFI, Stockholm University, SULCIS \\ and IZA Bonn
}

Discussion Paper No. 2402

October 2006

\author{
IZA \\ P.O. Box 7240 \\ 53072 Bonn \\ Germany \\ Phone: +49-228-3894-0 \\ Fax: +49-228-3894-180 \\ Email: iza@iza.org
}

\begin{abstract}
Any opinions expressed here are those of the author(s) and not those of the institute. Research disseminated by IZA may include views on policy, but the institute itself takes no institutional policy positions.

The Institute for the Study of Labor (IZA) in Bonn is a local and virtual international research center and a place of communication between science, politics and business. IZA is an independent nonprofit company supported by Deutsche Post World Net. The center is associated with the University of Bonn and offers a stimulating research environment through its research networks, research support, and visitors and doctoral programs. IZA engages in (i) original and internationally competitive research in all fields of labor economics, (ii) development of policy concepts, and (iii) dissemination of research results and concepts to the interested public.
\end{abstract}

IZA Discussion Papers often represent preliminary work and are circulated to encourage discussion. Citation of such a paper should account for its provisional character. A revised version may be available directly from the author. 


\section{ABSTRACT}

\section{Do the Unemployed Become Successful Entrepreneurs? A Comparison between the Unemployed, Inactive and Wage-Earners*}

In many countries unemployed people are helped to become self-employed. Selfemployment, however, does not necessarily lead to success. Many leave self-employment after a short period and the economic outcome varies greatly. It is important to learn more about the economic outcome for unemployed who become self-employed. In the first part of the paper we analyse who became self-employed in the period from 1999 to 2002 of Swedish-born men aged 20 to 60 years who were either wage-earners, unemployed or inactive in 1998. We find that the unemployed, and even more the inactive, are overrepresented among those who become self-employed. In the second part of the paper we study the economic outcome of self-employment in 2002 for Swedish-born men who were either unemployed, inactive or wage-earners in 1998. Economic outcome in 2002 is measured using income from self-employment and having employees in the firm. The estimations show that those who were wage earners in 1998 have higher incomes and are also employing other people in their business to a much higher extent in 2002 than those who in 1998 were unemployed or inactive. This indicates that support to unemployed to become self-employed should be implemented with great care.

JEL Classification: $\quad \mathrm{J} 23, \mathrm{~J} 24, \mathrm{~J} 30, \mathrm{~J} 60, \mathrm{~J} 62, \mathrm{~J} 68$

Keywords: self-employment, unemployment, inactive, occupational choice, occupational mobility, labour income, income

Corresponding author:

Eskil Wadensjö

Swedish Institute for Social Research

Stockholm University

SE 10691 Stockholm

Sweden

E-mail: Eskil.Wadensjo@sofi.su.se

\footnotetext{
* We would like to thank participants at the Applied Econometrics Association Conference on Policies against unemployment in Naples in June 2006 and a seminar at the Department of Economics, Aarhus School of Business for helpful comments on an earlier version. Financial support from IFAU is gratefully acknowledged.
} 


\section{Introduction}

In many countries the unemployed are helped to become self-employed. In Sweden, for example, start-up grants, which are a part of the active labour market policy, are paid out to unemployed individuals who turn to self-employment. Self-employment, however, is not always a success. Many leave self-employment after a short period of activity and some of them have acquired debts as a result of the attempt to establish themselves as self-employed. Also for those who continue as self-employed after the first critical period, the economic outcome varies greatly and the result may in some cases be a low economic standard. It is important to learn more about the economic outcome for those unemployed individuals who become self-employed in order to be able to evaluate the attempts to induce unemployed and to some extent also those outside the labour force to become self-employed.

In this paper we follow men born in Sweden who were either wage-earners, unemployed or inactive in 1998 during four years, i.e. to 2002. We identify those who became self-employed in 1999 and those of them who were also self-employed in 2002. Wage-earners are divided into three groups depending on the relation between the annual income they received in 1998 and the income they could be expected to receive according to estimations from an income regression of Mincer-type. Wage-earners can either have received a lower income than is predicted, an income close to the predicted one, or an income higher than the predicted one. These three groups of wage-earners and their propensity to become self-employed have been analysed earlier in Andersson and Wadensjö (2006).

The main objective of the paper is to compare the economic outcome and success as selfemployed of the five groups: the unemployed, the inactive, and three groups of wage-earners. Income from self-employment and number of employees in the firm are used as measures of economic outcome. We also estimate the probability of still being self-employed in 2002, conditional upon being self-employed in 1999. The question is if individuals who enter self- 
employment from a weak position on the labour market are equally successful as those who enter self-employment from a stronger position. Or is it rather the case that those entering from unemployment or inactivity have lower incomes, are more likely to not have any employees, and are more likely to exit self-employment?

The data used in this study is unique and consists of all Swedish-born men 20-60 years of age who lived in Sweden in 1998 and were either a wage-earner, unemployed or inactive that year. We exclude students and those receiving disability pensions. Unemployed are defined as those who had at least one day in unemployment during 1998 meaning that they have been registered at the employment office. The inactive are those who are not defined as wageearners and who have not been registered as unemployed at the employment office. Most of them have not received any labour income during the year.

The remainder of the paper is organised as follows. In section two earlier research is presented, in section three the data and econometric strategy is described, in section four we present summary statistics, in section five we present the results from the regression analysis, and in section six we summarise our findings and draw some conclusions.

\section{Earlier Research ${ }^{1}$}

There are reasons to believe that unemployed may be overrepresented among those who enter self-employment. Those who are unemployed may have a lower reservation income for being induced to take up self-employment. They may in a way be pushed into self-employment by not having the alternative to become a wage-earner. Empirical research also indicates that unemployed are more likely to enter self-employment than wage-earners are and also that those who are classified as inactive more often enter self-employment than the unemployed do. See Evans and Leighton (1989). That the unemployed more often enter self-employment than wage-earners does not mean that an increase in the general unemployment rate leads to

\footnotetext{
${ }^{1}$ See Parker (2004) for a comprehensive survey of research on self-employment.
} 
an increased self-employment rate - the propensity to enter self-employment may decline among unemployed as well as wage-earners (retaining the difference) to an extent that countervails the effect of the increase of the share being unemployed.

There are few studies of the economic results of self-employment. One reason is probably problems with reliability of the information on the incomes of the self-employed. Most studies have relied on the (employment) growth of the firms. The results vary greatly between studies (see Westhead and Cowling, 1995). That earlier unemployment experience is generally not included among the explanatory variables may be due to a lack of information.

The research on factors that influence exit from self-employment indicates that those who have entered self-employment from unemployment exit to a higher extent than those who have entered from paid employment. See Carrasco (1999) and Pfeiffer and Reize (2000).

\section{Data and Empirical Strategy}

\subsection{The Data}

The data used in this study is annual register data from Statistics Sweden which covers three years: 1998, 1999, and 2002. The data for 1998 includes all Swedish-born male wage-earners, inactive and unemployed between 20 and 60 years of age. In this data we can identify which individuals became self-employed in 1999. We observe the self-employed in 1999 and in 2002 which means that we can investigate how successful they are after only one year in business and for those who are still self-employed in 2002, their outcomes after four years in business. Since we know their labour market status in 1998 we have a unique opportunity to compare the outcomes between self-employed who entered from unemployment, inactivity, and from wage or salary work.

An individual is defined as a wage-earner if he: (i) was employed in November 1998, (ii) has not been registered as a student during the year, (iii) has not been registered as unemployed or 
received unemployment benefits anytime during the year, (iv) has not done the military service during the year, (v) has not received a disability pension, (vi) has not received social security payments equal to or greater than his labour income, (vii) has not been self-employed in 1998 and has not received any income from self-employment ${ }^{2}$, (viii) had an annual labour income in 1998 of at least 20000 SEK, and (ix) was not employed in agriculture or fishing.

Wage-earners have been further divided into three groups: (1) those who during 1998 received an annual income from labour lower than what we expect given observable characteristics, (2) those who had an annual income about as high as we expect it to be given observable characteristics, and (3) those who received an annual income from labour during 1998 which is higher than what we expect given observable characteristics. These three groups are identified from the estimation of an income regression using annual labour income in 1998 as the dependent variable. ${ }^{3}$ The first group consists of those for whom the estimated residual is negative, i.e. the actual income is lower than the predicted one. Explanations may be that it is a bad match or that they have low ability given the observed characteristics. The second group consists of those with an actual income close to predicted income. It may be an indication of a good match. The third group consists of those for which the residual is positive, i.e. the actual income is higher than the predicted income. One explanation may be that they have unobserved characteristics indicating high ability, maybe even higher than what the wage indicates. ${ }^{4}$

\footnotetext{
${ }^{2}$ Some individuals who are not classified as self-employed in a year may in spite of that have received some income from self-employment. This can happen if an individual is a wage-earner in November and receives his largest income in this month from that but has a smaller income from self-employment.

${ }^{3}$ See Andersson and Wadensjö (2006) for a discussion of the factors leading to that individuals get higher or lower wages than the expected ones.

${ }^{4}$ For dividing wage-earners into three groups we have identified the ratio at the $33^{\text {rd }}$ and $66^{\text {th }}$ percentiles of the ratio distribution. Individuals with a ratio equal to or lower than the ratio at the $33^{\text {rd }}$ percentile are classified as those with a low ratio, individuals with a ratio between the $33^{\text {rd }}$ and the $66^{\text {th }}$ percentile are classified as those with a ratio approximately equal to one, and those who have a value of the ratio higher than or equal to the ratio at the $66^{\text {th }}$ percentile are classified as those with a high ratio. Using this method to divide the population into ratio groups gives us three groups of about the same size.
} 
An individual is defined as unemployed if he: (i) has been registered as unemployed at least one day during the year, (ii) is not defined as a wage-earner, (iii) has not been registered as student during the year, (iv) has not done military service during the year, (v) has not received a disability pension, and (vi) has not been self-employed in 1998 and has not received any income from self-employment.

An individual has been defined as inactive in 1998 if he; (i) is not defined as a wage-earner, (ii) has not been registered as unemployed or received unemployment benefits any time during the year, (iii) has not been registered as a student during the year, (iv) has not done military service during the year, (v) has not received a disability pension, and (vi) has not been self-employed in 1998 and has not received any income from self-employment.

Students and disability pensioners are excluded from the analysis.

An individual is defined as being self-employed in 1999 if he has received an income from self-employment and if the monthly income from self-employment multiplied with a factor of 1.6 exceeds the income from wage or salary work in November. ${ }^{5}$ This is the definition used by Statistics Sweden in the annual employment register which the data used in this paper is based on. Adopting this definition means that some of the self-employed in 1999 may have worked part-time or part-year as a wage-earner, for example in the same firm as in 1998. The definition of being self-employed in 1999 is not made conditional upon that the firm started in 1999. Some of those who became self-employed in 1999 may have taken over an already existing firm.

\footnotetext{
${ }^{5}$ When comparing wage income and self-employment income the income from self-employment is multiplied by the factor 1.6 since the self-employed in general, according to Statistics Sweden, receive lower incomes. To get the monthly income from self-employment, the annual income is divided by 12. In the population studied in this paper there are two types of self-employed; those whose firm is registered as a limited liability company and those with a private firm.
} 


\subsection{Empirical Strategy}

In the first part of the empirical analysis we investigate which of the groups that are most likely to become self-employed. This model is based on all observations in the data and is estimated using a probit model. Four specifications of the model are estimated. First we divide the whole population into three groups: wage-earners, inactive, and unemployed. We estimate the difference between these groups both with and without controlling for differences between the groups regarding age, education, marital status, place of residence, and being a second-generation immigrant. Second, the population is divided into five groups where the wage-earners are split into three groups depending on the relation between their actual income and their predicted income. In all models where the population is divided into five categories, wage-earners who received an annual income close to the expected are the excluded group (the reference group). We also control for days in unemployment. This variable is zero for all groups except for the unemployed. For the unemployed it varies from 1 to 365 with an average value of 160 days in unemployment. The reason for why we include this variable is that the propensity to become self-employed may differ between long-term and short-term unemployed. Also in this case estimations are made both with and without additional covariates.

The rest of the analysis is based on the populations of self-employed in 1999 and 2002. We estimate differences in income from self-employment and differences in the solo entrepreneur share between the groups. The same specifications of the model as before are estimated for the outcomes. Control for number of days in unemployment is included in these regressions and we also control for whether one received a start-up subsidy in 1998. We first investigate whether there are any income differences in 1999, i.e. in the same year as they became selfemployed. For those who also are self-employed in 2002, we estimate self-employment income regressions for that year. The probability of being a solo entrepreneur, i.e. to not have 
any employees, is estimated in 1999, and also in 2002 conditional upon being self-employed also in 2002. ${ }^{6}$

We do not expect that also being self-employed in 2002 is random, those who are less successful in 1999 can be expected to be more likely to exit self-employment. The choice to exit self-employment and destination after self-employment can be seen as a measure of the success as self-employed, but also successful self-employed may exit self-employment if they receive an attractive employment offer. Conditional on being self-employed in 1999 we estimate the probability of still being self-employed in 2002. The dependent variable is labelled "exit" and is equal to one if one is no longer self-employed in 2002 and zero if one is self-employed also in 2002. From earlier studies we know that destination after exit differs between groups so it is important to not only consider the risk of exiting self-employment, but also if the destination is wage or salary work, unemployment or inactivity (Andersson, 2006, Johansson, 2001, Taylor, 1999). Successful self-employed may more often become wageearners, while the less successful ones may more often exit to unemployment. We define three types of labour market status in 2002: self-employment (i.e. those who did not exit), wageearners, and “other”. The group "other” includes both unemployed and inactive. Since the dependent variable now consists of three categories we estimate a multinomial model where not exiting self-employment is used as the reference category.

\section{Descriptive statistics}

In Table 1a summary statistics for age, education, marital status, place of residence, family background, and annual labour income in 1998 are presented for the five groups. The division of wage-earners into three groups has as earlier mentioned been done by a comparison of the actual annual income they received in 1998 with their predicted annual income. The predicted

\footnotetext{
${ }^{6}$ Since we have not considered labour market status in 2000 and 2001 there is a possibility that some of the selfemployed have been wage-earners, unemployed or have done something else in 2000 or 2001 and have started a new firm in 2001 and 2002. In this paper we do not explore this possibility further.
} 
income is calculated from a standard income regression with controls for age, education, marital status, having young children, place of residence, and second-generation immigrants. For a thorough comparison and analysis of these groups of wage-earners, see Andersson and Wadensjö (2006).

Wage-earners who received a lower income than the predicted one in 1998 are on average 42 years of age which makes them the second oldest group. The oldest are those who in 1998 has been categorised as inactive. In this group, around 19 per cent are between 56 and 60 years of age. The unemployed is with an average age of 37.6 years the youngest group. Among the unemployed almost 21 per cent are between 20 and 25 years old compared to only 7 per cent among those who are paid as expected.

The unemployed have lower education than the wage-earners who are paid as expected. Almost 32 per cent of the unemployed have primary school as their highest education and only 11 per cent have a university education. Among wage-earners who are paid as expected the corresponding shares are 23 and 24 per cent, respectively.

It is more common among all three groups of wage-earners than among the inactive and the unemployed to be married and have small children. The share of inactive that resides in a metropolitan area is almost 9 percentage units higher than that of wage-earners who receive an income of about the same size as the predicted one; 38 per cent compared to 29 per cent.

Start-up subsidies are of course most common among those who were unemployed in 1998 as unemployment is a requisite for receiving the subsidy, but there are some who have received a start-up subsidy also among the other four groups, especially among those who were inactive in 1998. The explanation is that some of them may have become unemployed in 1999 and after that received a start-up subsidy.

[TABLE 1A ABOUT HERE] 
In Table $1 b$ we present the number and share of individuals in the different groups that leave wage or salary work, inactivity, and unemployment to become self-employed. For those who become self-employed, average value of the outcomes in 1999, income and share that are solo entrepreneurs, i.e. they have no employees, are presented. Since we follow in the data those who become self-employed up to 2002, we also present the outcomes in 2002 for those who are still self-employed that year. The unemployed who become self-employed may be less successful in the beginning. By looking at the outcomes three years after start we can see if the disadvantage has diminished. Measuring outcome in 2002 is conditional upon survival as self-employed and exits from self-employment can also be used as an indication of success as self-employed. However, some self-employed that exit may do so not as a result of unsuccessful business but because they have received an attractive employment offer. Therefore we study not only exits in general terms but also destinations after self-employment. It was most common among the inactive to turn to self-employment in 1999. Around 6 per cent left inactivity to become self-employed. Among the unemployed, 2 per cent became selfemployed, and among all three groups of wage-earners, less than 1 per cent became selfemployed. Among the wage-earners, the share becoming self-employed was highest among those who received a lower income than expected, 0.72 per cent, and lowest among those who were paid as expected, 0.36 per cent.

There are large differences in the incomes received in 1999 from self-employment between the different groups. Wage-earners who received a higher income than predicted earn on average 253250 SEK (approx. €26 800) from self-employment during 1999, while those who entered from unemployment earn on average 66138 SEK (approx. €7 000). Hence without controlling for age, education, or industry of the firm, the formerly unemployed earn as selfemployed on average 74 per cent less than the most successful wage-earners earn as selfemployed. There are also substantial differences in self-employment income between the 
three different groups of wage-earners where those who received a lower income than expected have the lowest self-employment incomes.

Whether the self-employed can hire employees is often seen as a measure of success of the firm and this aspect of self-employment is also important in the political debate about entrepreneurship and small businesses. One motive for encouraging self-employment is that it should create new jobs for more people than the self-employed himself. We find the same type of difference between the groups as we did regarding income: successful wage-earners appear to be the most successful self-employed. Around 58 per cent in this group are so called solo entrepreneurs, i.e. they do not have any employees but this means that 42 per cent already have employees in the first year as self-employed. Among those who entered from unemployment only around 9 per cent have employees.

Out of those who became self-employed in 1999, in total 59 per cent were also self-employed in 2002. The shares differ between the groups. Among those who in 1998 were unemployed 49 per cent were no longer self-employed in 2002, while 32 per cent among those who as wage-earners were paid as expected had exited before 2002. Looking at destination after selfemployment we detect even larger differences between the groups. For example, 28 per cent of the wage-earners with a higher income than the predicted one had exited self-employment before 2002 and were wage-earners in 2002. The corresponding share among the formerly unemployed is 19 per cent and among the formerly inactive only 15 per cent.

Here we see a clear pattern regarding differences between the groups. Those who were successful on the labour market before they became self-employed, i.e. were employed and received a higher income than expected, also appear to perform better than those who entered self-employment from a less fortunate position, i.e. who either were unemployed or inactive. In the regression analysis we consider differences in characteristics as age, education and industry when the outcomes are analysed. 
Part of the explanation for these large differences is that there is a selection of individuals into wage or salary work, unemployment and inactivity. Those who are more established on the labour market and in society in general also have the advantage of having a larger network, more acquaintances and former colleagues which can be of help when one chooses to become self-employed. Those with a weaker connection to the labour market might have more difficulties in attracting customers and getting good prices from suppliers.

Another explanation for the large differences, especially concerning income, is that the inactive and the unemployed are likely to have a lower reservation wage. The expected income from self-employment does not need to be very high in order for self-employment to become a more attractive alternative than unemployment or inactivity. Also, it is not only the expected income from self-employment that matters. To create a job for oneself and avoid being dependent on benefits is likely to be very important for many people without work.

[TABLE 1B ABOUT HERE]

\section{The Probability of Becoming Self-Employed}

We now continue by presenting the results from the different regressions. We start by in Table 2 presenting the results regarding the probability of becoming self-employed. Focusing on the results of models (3) and (4) where we include additional controls, we see from model (3) that the probability for the inactive of becoming self-employed is 6.9 percentage units higher and the probability of becoming self-employed for the unemployed is 1.9 percentage units higher than that for the whole group of wage-earners. Most surprising is maybe the strong tendency to become self-employed among the inactive. ${ }^{7}$

When wage-earners are divided into the three different groups with wage-earners who received an income close to the predicted one as reference group, we find that all four groups

\footnotetext{
${ }^{7}$ The results indicate that the inactive should be more in focus in the study of labour supply and the transition to different forms of employment. See also Blackaby et al. (2006).
} 
have a significantly higher probability of becoming self-employed than the reference group. The probability is highest for the inactive, 8.4 percentage units higher than the reference group.

Here we also control for number of days in unemployment which has been transformed in hundreds of days as unemployed during the year. The effect is not very large, but it has a negative sign and is significantly different from zero. This means that an increase in days in unemployment decreases the probability of becoming self-employed. This suggests that the short-term unemployed are overrepresented among the unemployed who become selfemployed.

[TABLE 2 ABOUT HERE]

\section{Self-Employment Outcomes}

We will now turn to study the outcomes as self-employed for the five groups and start by showing results from regressions with income (log income from self-employment in 1999) as the outcome variable. Interpreting the result from model (4) we find that wage-earners who received a lower income than predicted have 21.6 per cent lower incomes from selfemployment, wage-earners who received a higher income than predicted have 31.4 per cent higher incomes, the formerly inactive have on average 56.6 per cent lower incomes, and the previously unemployed on average 61.9 per cent lower incomes, all compared to wageearners who received an income close to the predicted one. We also find that the income from self-employment declines with the number of days in unemployment, and that receiving a start-up subsidy is combined with an income higher than that for those who did not receive a subsidy. That those with a start-up subsidy get a higher income may be explained by the support (economic and advice) but also by that the employment office gives support to those among the unemployed who are best equipped to be successful as self-employed. 


\section{[TABLE 3 ABOUT HERE]}

If the corresponding income regression is estimated for those who are also self-employed in 2002, we find that the coefficients for all groups have declined, i.e. the income differences between the groups are smaller. Wage-earners who received a lower income than predicted in 2002 have 20.9 per cent lower incomes from self-employment, wage-earners who received a higher income than the predicted one have 23.4 per cent higher incomes, the formerly inactive have on average 53.4 per cent lower incomes, and the formerly unemployed have on average 49.0 per cent lower incomes, all compared to wage-earners who receive an income close to the predicted one. Those who entered self-employment from unemployment appear to be catching up better than the formerly inactive. The differences are all still large, however. Those unemployed who received a start-up grant in 1998 in 2002 still have higher incomes than the unemployed who did not receive one. The incomes they receive are, however, lower that the incomes of those who were wage-earners in 1998 and in 1999 became self-employed.

\section{[TABLE 4 ABOUT HERE]}

The number of employees the self-employed has is a measure of success in the sense that the better the economy of the firm the higher is the need for hiring co-workers. We find a similar pattern regarding the probability of being a solo entrepreneur, i.e. to have no employees, as we did for income. See Table 5. The previously inactive and the previously unemployed are significantly more likely, both compared to the whole group of wage-earners and to wageearners who received an income close to the predicted one, to be solo entrepreneurs. Days in unemployment and start-up subsidy (included in model 4) do not have a significant effect.

\section{[TABLE 5 ABOUT HERE]}

From the summary statistics we learnt that a larger share of the self-employed had employees in 2002 than in 1999. The probability of having employees increases with time spent in selfemployment. In spite of that the number of employees increases in all groups of self- 
employed, the increase is smaller among the previously inactive and unemployed. We see this from the regressions presented in Table 6 where the estimated marginal effects for the probability of being a solo entrepreneur in 2002 is larger than the corresponding marginal effects calculated for 1999. The formerly unemployed do not seem to catch up with the former wage-earners regarding the number of employees, at least not in the period we cover. Those who have received a start-up subsidy have more often employees.

\section{[TABLE 6 ABOUT HERE]}

Income from self-employment and the number of employees in 2002 can only be observed for those who also are self-employed that year and it is likely that the more successful ones belong to this group even if some of the successful self-employed might have left to become wage-earners. Therefore it is of interest to see how the risk of not being self-employed in 2002, conditional on being self-employed in 1999, differs between the groups. These results are presented in Table 7. The reference group is still wage-earners or if we have five groups. those who as wage-earners received an annual income close to the predicted one. Those who as wage-earners received a lower income than predicted have a 6.3 percentage units higher probability of no longer being self-employed in 2002, those who received a higher income than expected have a 3.2 percentage units higher probability, the formerly inactive have a 11.4 percentage units higher probability, and the formerly unemployed have a 19.3 percentage units higher probability of not being self-employed in 2002. Having received a start-up

subsidy decreases the risk of exiting self-employment with 7.7 per cent, while days in unemployment in 1998 (the year before becoming self-employed) have no significant effect.

\section{[TABLE 7 ABOUT HERE]}

We argued earlier that it is important to consider destination after self-employment. In Table 8 we present the results from the multinomial model. As a comparison, model (4) from Table 7 has been re-estimated with a logit instead of a probit model and coefficient values are 
presented instead of marginal effects. From the earlier probit we concluded that all groups are more likely to have exited from self-employment in 2002 compared to those who were paid as expected when they were wage-earners. The multinomial model shows that wage-earners who received a higher income than predicted exit self-employment to become wage-earners again while the previously inactive and unemployed less likely to become wage-earners and more often exit for another labour market status. The previous unemployed who have received a start-up subsidy are much less likely to re-enter unemployment than those who previously were unemployed and entered self-employment without receiving a start-up grant.

\section{[TABLE 8 ABOUT HERE]}

We have shown in this analysis that self-employed who have entered from unemployment or inactivity do not appear to become as successful entrepreneurs as wage-earners who become self-employed or the particular group of wage-earners who received an income close to the predicted one. We have already argued that there are several types of selection which might influence our results. There is a selection into labour market status in 1998; it is not random who are unemployed, inactive or wage-earners. There is also a selection into self-employment and there is a selection out of self-employment. But we have in this study shown that groups who enter self-employment from a weak position on the labour market are likely to be affected by this position for a long period. Even those who also were self-employed in 2002, four years after unemployment and inactivity, have substantially lower incomes from selfemployment than those who were wage-earners have. But we will underline that we do not know what would have happened to these individuals if they had not chosen to become selfemployed. Perhaps their incomes and their situation in general had been worse if they had not become self-employed. 


\section{Summary and Conclusion}

We are comparing five different groups: 1) those who were unemployed in 1998, 2) those who were inactive in 1998, 3) wage-earners who in 1998 had an income lower than the income predicted by their observable characteristics (age, education, marital status, place of residence), 4) wage-earners who in 1998 had an income about the same as the income predicted by their observable characteristics, and 5) wage-earners who in 1998 had an income higher than the income predicted by their observable characteristics. We compare them regarding their propensity to become self-employed, their results as self-employed, and their propensity to leave self-employment.

The propensity to become self-employed is highest among the inactive, and second highest among the unemployed. The propensity is much lower among wage-earners. This indicates that push-factors are important. Among the wage-earners, those with actual incomes higher than predicted and those with lower incomes than predicted more often become self-employed than those with incomes about as expected given their observed characteristics. Different forms of imbalances may explain this pattern.

The results of the econometric estimations show that the outcome differs much between the five groups. The group with the best economic results are wage-earners who in 1998 had an income higher than the income predicted by their observable characteristics. They have higher incomes and are also employing other people in their business to a much higher extent. Those with an income lower than the income predicted by their observable characteristics, the unemployed and the inactive have on average less satisfying economic outcomes. This does not mean that all former unemployed or inactive are doing poorly as self-employed.

The individuals who were inactive or unemployed before entering self-employment exit to a higher extent from self-employment than the former wage-earners do. The former wageearners who exit also to a high extent go to paid work while the previously unemployed and 
inactive go back to those labour market statuses. These results are a further indication of the differences in the situation of the different groups.

An interesting result is that the unemployed who have a start-up subsidy are doing better than unemployed without a subsidy in different respects (income, number of employees, exit). The explanation may be the result of the subsidy and the help in starting a firm given the employment office, but it may also be a selection effect, i.e. that the case worker select the candidates most suited for self-employment.

\section{References}

Andersson, P. (2006), “Determinants of Exits from Self-Employment”, in Andersson, P, Four Essays on Self-Employment, Swedish Institute for Social Research, Dissertation Series No. 69.

Andersson, P. and Wadensjö, E. (2006), "Wage-Earners who Become Self-Employed: The Impact of Income and Wages”, in Andersson, P, Four Essays on Self-Employment, Swedish Institute for Social Research, Dissertation Series No. 69.

Blackaby, D. H., Latreille, P. L., Murphy, P. D. and O’Leary, N. (2006), “An Analysis of Reservation Wages for Economically Inactive”, IZA Discussion Paper No. 1980.

Carrasco, R. (1999), “Transitions to and from self-employment in Spain”, Oxford Bulletin of Economics and Statistics, 61, no. 3, pp. 315-341.

Evans, D. S. and Leighton, L. S. (1989), “Some Empirical Aspects of Entrepreneurship”, American Economic Review, vol. 79, no. 3, pp. 519-535.

Johansson, E. (2000), “Determinants of Self-Employment Duration - Evidence from Finnish Micro-Data”, in Essays on the Determinants of Self-Employment, Ekonomi och Samhälle, Nr 85, Swedish School of Economics and Business Administration, Finland.

Parker, S. C. (2004), The Economics of Self-Employment and Entrepreneurship, Cambridge University Press, Cambridge.

Pfeiffer, F. and Reize, F. (2000), "Business start-ups by the unemployed - an econometric analysis based on firm data”, Labour Economics, vol. 7, no. 5, pp. 629-663.

Taylor, M. (1999), "Survival of the Fittest? An Analysis of Self-Employment Duration in Britain”, Economic Journal, vol. 109, no. 454, pp. C140-155.

Westhead, P. and Cowling, M. (1995), "Employment change in independent owner-managed high-technology firms in Great Britain”, Small Business Economics, vol. 7, pp.111-140. 
Table 1a Summary statistics. All variables are measured in 1998

\begin{tabular}{|c|c|c|c|c|c|}
\hline & $\begin{array}{c}\text { Lower } \\
\text { income than } \\
\text { predicted }\end{array}$ & $\begin{array}{c}\text { Income } \\
\text { about as } \\
\text { predicted }\end{array}$ & $\begin{array}{c}\text { Higher } \\
\text { income than } \\
\text { predicted }\end{array}$ & Inactive & Unemployed \\
\hline Age (years) & 42.0 & 40.8 & 40.6 & 42.3 & 37.6 \\
\hline \multicolumn{6}{|l|}{ Age groups (\%) } \\
\hline $20-25$ & 6.2 & 6.6 & 10.1 & 11.0 & 20.8 \\
\hline $26-30$ & 10.4 & 14.1 & 12.9 & 10.9 & 14.7 \\
\hline 31-35 & 13.9 & 16.2 & 14.5 & 11.9 & 13.7 \\
\hline $36-40$ & 13.3 & 13.2 & 12.5 & 11.0 & 10.6 \\
\hline $41-45$ & 14.1 & 13.0 & 12.7 & 10.8 & 9.9 \\
\hline $46-50$ & 15.5 & 13.3 & 13.6 & 11.8 & 10.0 \\
\hline $51-55$ & 16.5 & 14.3 & 14.5 & 13.4 & 10.9 \\
\hline $56-60$ & 10.1 & 9.4 & 9.3 & 19.3 & 9.4 \\
\hline \multicolumn{6}{|l|}{ Education (\%) } \\
\hline Primary school less than 9 years & 6.7 & 10.0 & 7.0 & 11.4 & 8.5 \\
\hline Primary school 9(10) years & 10.7 & 13.1 & 11.9 & 19.9 & 23.1 \\
\hline Upper secondary 2 years or less & 30.3 & 36.4 & 31.3 & 31.3 & 38.9 \\
\hline Upper secondary more than 2 years & 18.3 & 16.3 & 18.4 & 17.1 & 18.4 \\
\hline Higher education less than 3 years & 15.4 & 13.8 & 15.1 & 10.5 & 7.8 \\
\hline Higher education 3 years or more & 17.3 & 9.4 & 15.0 & 9.3 & 3.3 \\
\hline Post graduate education & 1.4 & 0.8 & 1.3 & 0.6 & 0.1 \\
\hline \multicolumn{6}{|l|}{ Marital status (\%) } \\
\hline Married & 52.3 & 45.5 & 45.1 & 32.0 & 19.5 \\
\hline Cohabiting with children & 10.7 & 12.7 & 11.0 & 6.4 & 7.8 \\
\hline Other & 37.0 & 41.8 & 43.9 & 61.6 & 72.7 \\
\hline Small children (\%) & 21.1 & 21.5 & 20.1 & 9.8 & 10.5 \\
\hline \multicolumn{6}{|l|}{ Place of residence (\%) } \\
\hline $\begin{array}{l}\text { Metropolitan areas (Stockholm, } \\
\text { Gothenburg, Malmoe) }\end{array}$ & 35.8 & 28.9 & 34.2 & 38.3 & 25.8 \\
\hline \multicolumn{6}{|l|}{ Family background (\%) } \\
\hline Both parents born abroad & 2.8 & 2.8 & 3.1 & 5.1 & 5.5 \\
\hline One parent born abroad & 10.8 & 10.5 & 10.9 & 14.9 & 13.7 \\
\hline \multicolumn{6}{|l|}{ Other variables } \\
\hline Unemployment days in 1998 & 0 & 0 & 0 & 0 & 160 \\
\hline Start-up subsidy (\%) & 0.1 & 0.02 & 0.02 & 0.6 & 1.9 \\
\hline Income from work (SEK) & 192277 & 245471 & 372441 & 14297 & 19784 \\
\hline Number of observations & 409381 & 409383 & 421780 & 77160 & 124094 \\
\hline
\end{tabular}


Table 1b Summary statistics of dependent variables

\begin{tabular}{|c|c|c|c|c|c|}
\hline & $\begin{array}{c}\text { Lower } \\
\text { income than } \\
\text { predicted }\end{array}$ & $\begin{array}{l}\text { Income about as } \\
\text { predicted }\end{array}$ & $\begin{array}{l}\text { Higher income } \\
\text { than predicted }\end{array}$ & Inactive & Unemployed \\
\hline Self-employed in 1999 (per cent) & $2942(0.72 \%)$ & $1489(0.36 \%)$ & $1829(0.43 \%)$ & $4907(6.4 \%)$ & $2421(2.0 \%)$ \\
\hline $\begin{array}{l}\text { Income from self-employment } \\
\text { in } 1999 \text { (SEK) }\end{array}$ & 130967 & 170220 & 253248 & 83483 & 66138 \\
\hline Share with no employees in 1999 & $66.2 \%$ & $65.7 \%$ & $58.3 \%$ & $83.8 \%$ & $92.4 \%$ \\
\hline $\begin{array}{l}\text { Still self-employed in } 2002 \\
\text { (per cent) }\end{array}$ & $1800(61.2 \%)$ & $1009(67.8 \%)$ & $1131(61.8 \%)$ & $2762(56.3 \%)$ & $1245(51.4 \%)$ \\
\hline $\begin{array}{l}\text { Income from self-employment } \\
\text { in } 2002 \text { (SEK) }\end{array}$ & 190146 & 236801 & 318963 & 128464 & 131867 \\
\hline Share with no employees in 2002 & $59.6 \%$ & $52.2 \%$ & $50.1 \%$ & $80.8 \%$ & $84.8 \%$ \\
\hline $\begin{array}{l}\text { Exits self-employment before } \\
2002\end{array}$ & $38.8 \%$ & $32.2 \%$ & $38.2 \%$ & $43.7 \%$ & $48.6 \%$ \\
\hline \multicolumn{6}{|l|}{ Destination after self-employment } \\
\hline Wage-earner & $22.9 \%$ & $23.5 \%$ & $28.1 \%$ & $14.7 \%$ & $18.9 \%$ \\
\hline Other & $15.4 \%$ & $8.3 \%$ & $9.6 \%$ & $28.0 \%$ & $29.2 \%$ \\
\hline Number of observations & 409381 & 409383 & 421780 & 77160 & 124094 \\
\hline
\end{tabular}


Table 2 Probability of becoming self-employed in 1999, marginal effects

\begin{tabular}{|c|c|c|c|c|}
\hline & $\begin{array}{c}(1) \\
\text { Pr(Self- } \\
\text { Employed) }\end{array}$ & $\begin{array}{c}(2) \\
\text { Pr(Self- } \\
\text { Employed) }\end{array}$ & $\begin{array}{c}(3) \\
\text { Pr(Self- } \\
\text { Employed) }\end{array}$ & $\begin{array}{c}(4) \\
\text { Pr(Self- } \\
\text { Employed) }\end{array}$ \\
\hline $\begin{array}{l}\text { Labour market status in } 1998 \\
\text { Wage-earner }\end{array}$ & Ref. & & Ref. & \\
\hline $\begin{array}{l}\text { Lower income than predicted } \\
\text { as wage-earner } \\
\text { Income about as predicted } \\
\text { as wage-earner }\end{array}$ & & $\begin{array}{l}0.0049 \\
(0.0003)^{* *} \\
\text { Ref. }\end{array}$ & & $\begin{array}{c}0.0048 \\
(0.0003)^{* *} \\
\text { Ref. }\end{array}$ \\
\hline $\begin{array}{l}\text { Higher income than predicted } \\
\text { as wage-earner }\end{array}$ & & 0.0011 & & 0.0013 \\
\hline Inactive & $\begin{array}{c}0.0635 \\
(0.0009)^{* *}\end{array}$ & $\begin{array}{c}0.0772 \\
(0.0015)^{* *}\end{array}$ & $\begin{array}{c}0.0693 \\
(0.0011)^{* *}\end{array}$ & $\begin{array}{c}0.0841 \\
(0.0016)^{* *}\end{array}$ \\
\hline Unemployed & $\begin{array}{c}0.0164 \\
(0.0004)^{* *}\end{array}$ & $\begin{array}{c}0.0284 \\
(0.0013)^{* *} \\
(0.0002)^{* *}\end{array}$ & $\begin{array}{c}0.0191 \\
(0.0005)^{* *}\end{array}$ & $\begin{array}{c}0.0333 \\
(0.0015)^{* *} \\
(0.0002)^{* *}\end{array}$ \\
\hline Number of unemployment days & & $\begin{array}{l}-0.0012 \\
(0.0002)^{* *}\end{array}$ & & $\begin{array}{c}-0.0013 \\
(0.0002)^{* *}\end{array}$ \\
\hline Additional controls & No & No & Yes & Yes \\
\hline Number of observations & 1441798 & 1441798 & 1441798 & 1441798 \\
\hline
\end{tabular}




\begin{tabular}{|c|c|c|c|c|}
\hline & $\begin{array}{c}(1) \\
\text { Ln(income) }\end{array}$ & $\begin{array}{c}(2) \\
\operatorname{Ln}(\text { income) } \\
\end{array}$ & $\begin{array}{c}(3) \\
\text { Ln(income) }\end{array}$ & $\begin{array}{c}(4) \\
\text { Ln(income) }\end{array}$ \\
\hline $\begin{array}{l}\text { Labour market status in } 1998 \\
\text { Wage-earner }\end{array}$ & Ref. & & Ref. & \\
\hline $\begin{array}{l}\text { Lower income than predicted } \\
\text { as wage-earner }\end{array}$ & & $\begin{array}{c}-0.283 \\
(0.038)^{* * *}\end{array}$ & & $\begin{array}{c}-0.244 \\
(0.037)^{* * *}\end{array}$ \\
\hline $\begin{array}{l}\text { Income about as predicted } \\
\text { as wage-earner }\end{array}$ & & Ref. & & Ref. \\
\hline $\begin{array}{l}\text { Higher income than predicted } \\
\text { as wage-earner }\end{array}$ & & $\begin{array}{c}0.313 \\
(0.044)^{* * *}\end{array}$ & & $\begin{array}{c}0.273 \\
(0.043)^{* * *}\end{array}$ \\
\hline Inactive & $\begin{array}{c}-1.019 \\
(0.028)^{* * *}\end{array}$ & $\begin{array}{c}-1.063 \\
(0.038)^{* * *}\end{array}$ & $\begin{array}{c}-0.782 \\
(0.028)^{* * *}\end{array}$ & $\begin{array}{c}-0.834 \\
(0.038)^{* * *}\end{array}$ \\
\hline Unemployed & $\begin{array}{c}-1.168 \\
(0.035)^{* * *}\end{array}$ & $\begin{array}{c}-1.154 \\
(0.065)^{* * *}\end{array}$ & $\begin{array}{c}-1.048 \\
(0.035)^{* * *}\end{array}$ & $\begin{array}{c}-0.964 \\
(0.065)^{* * *}\end{array}$ \\
\hline $\begin{array}{l}\text { Number of days in unemployment } \\
\text { in } 1998 / 100\end{array}$ & & $\begin{array}{c}-0.102 \\
(0.032)^{* * *}\end{array}$ & & $\begin{array}{c}-0.130 \\
(0.032)^{* * *}\end{array}$ \\
\hline Start-up subsidy & & $\begin{array}{c}0.335 \\
(0.048)^{* * *}\end{array}$ & & $\begin{array}{c}0.237 \\
(0.048)^{* * *}\end{array}$ \\
\hline $\begin{array}{l}\text { Constant } \\
\text { Additional controls }\end{array}$ & $\begin{array}{c}11.616 \\
(0.016)^{* * *} \\
\text { No }\end{array}$ & $\begin{array}{c}11.649 \\
(0.030)^{* * *} \\
\text { No }\end{array}$ & $\begin{array}{c}11.050 \\
(0.060)^{* * *} \\
\text { Yes }\end{array}$ & $\begin{array}{c}11.059 \\
(0.066)^{* * *} \\
\text { Yes }\end{array}$ \\
\hline Number of observations & 13527 & 13527 & 13527 & 13527 \\
\hline R-squared & 0.12 & 0.14 & 0.18 & 0.19 \\
\hline
\end{tabular}




\begin{tabular}{|c|c|c|c|c|}
\hline & $\begin{array}{c}(1) \\
\operatorname{Ln}(\text { income }) \\
\end{array}$ & $\begin{array}{c}(2) \\
\text { Ln(income) }\end{array}$ & $\begin{array}{c}(3) \\
\operatorname{Ln}(\text { income }) \\
\end{array}$ & $\begin{array}{c}(4) \\
\operatorname{Ln}(\text { income) }\end{array}$ \\
\hline Labour market status in 1998 & & & & \\
\hline Wage-earner & Ref. & & Ref. & \\
\hline $\begin{array}{l}\text { Lower income than predicted } \\
\text { as wage-earner }\end{array}$ & & $\begin{array}{c}-0.269 \\
(0.043)^{* * *}\end{array}$ & & $\begin{array}{c}-0.234 \\
(0.031)^{* * *}\end{array}$ \\
\hline $\begin{array}{l}\text { Income about as predicted } \\
\text { as wage-earner }\end{array}$ & & Ref. & & Ref. \\
\hline $\begin{array}{l}\text { Higher income than predicted } \\
\text { as wage-earner }\end{array}$ & & $\begin{array}{c}0.222 \\
(0.048)^{* * *}\end{array}$ & & $\begin{array}{c}0.210 \\
(0.036)^{* * *}\end{array}$ \\
\hline Inactive & $\begin{array}{c}-0.908 \\
(0.028)^{* * *}\end{array}$ & $\begin{array}{c}-0.968 \\
(0.041)^{* * *}\end{array}$ & $\begin{array}{c}-0.701 \\
(0.031)^{* * *}\end{array}$ & $\begin{array}{c}-0.763 \\
(0.037)^{* * *}\end{array}$ \\
\hline Unemployed & $\begin{array}{c}-0.720 \\
(0.036)^{* * *}\end{array}$ & $\begin{array}{c}-0.781 \\
(0.071)^{* * *}\end{array}$ & $\begin{array}{c}-0.649 \\
(0.034)^{* * *}\end{array}$ & $\begin{array}{c}-0.673 \\
(0.069)^{* * *}\end{array}$ \\
\hline $\begin{array}{l}\text { Number of days in unemployment } \\
\text { in } 1998 / 100\end{array}$ & & $\begin{array}{l}-0.053 \\
(0.033)\end{array}$ & & $\begin{array}{c}-0.057 \\
(0.034) *\end{array}$ \\
\hline Start-up subsidy & & $\begin{array}{c}0.247 \\
(0.052)^{* * *}\end{array}$ & & $\begin{array}{c}0.170 \\
(0.049)^{* * *}\end{array}$ \\
\hline Constant & $\begin{array}{c}12.139 \\
(0.018)^{* * *}\end{array}$ & $\begin{array}{c}12.192 \\
(0.035)^{* * *}\end{array}$ & $\begin{array}{c}11.792 \\
(0.067)^{* * *}\end{array}$ & $\begin{array}{c}11.817 \\
(0.069)^{* * *}\end{array}$ \\
\hline Additional controls & $\frac{\text { No }}{7921}$ & $\frac{\mathrm{No}}{7021}$ & $\frac{\text { Yes }}{7921}$ & $\frac{\text { Yes }}{7921}$ \\
\hline $\begin{array}{l}\text { Number of observations } \\
\text { R-squared }\end{array}$ & $\begin{array}{c}7921 \\
0.13\end{array}$ & $\begin{array}{c}7921 \\
0.15\end{array}$ & $\begin{array}{c}7921 \\
0.19\end{array}$ & $\begin{array}{c}7921 \\
0.21\end{array}$ \\
\hline
\end{tabular}


Table 5 Probability of being a solo entrepreneur (solo) in 1999, marginal effects

\begin{tabular}{|c|c|c|c|c|}
\hline & $\begin{array}{c}(1) \\
\operatorname{Pr}(\text { solo })\end{array}$ & $\begin{array}{c}(2) \\
\operatorname{Pr}(\text { solo })\end{array}$ & $\begin{array}{c}\text { (3) } \\
\operatorname{Pr}(\text { solo) }\end{array}$ & $\begin{array}{c}\text { (4) } \\
\text { Pr(solo) }\end{array}$ \\
\hline \multicolumn{5}{|l|}{ Labour market status in 1998} \\
\hline Wage-earner & Ref. & & Ref. & \\
\hline $\begin{array}{l}\text { Lower income than predicted as } \\
\text { wage-earner }\end{array}$ & & $\begin{array}{c}0.028 \\
(0.012)^{* *}\end{array}$ & & $\begin{array}{c}0.017 \\
(0.011)\end{array}$ \\
\hline $\begin{array}{l}\text { Income about as predicted as } \\
\text { wage-earner }\end{array}$ & & Ref. & & Ref. \\
\hline $\begin{array}{l}\text { Higher income than predicted as } \\
\text { wage-earner }\end{array}$ & & $\begin{array}{c}-0.036 \\
(0.014)^{* *}\end{array}$ & & $\begin{array}{c}-0.060 \\
(0.014)^{* * *}\end{array}$ \\
\hline Inactive & $\begin{array}{c}0.180 \\
(0.007)^{* * *}\end{array}$ & $\begin{array}{c}0.182 \\
(0.010)^{* * *}\end{array}$ & $\begin{array}{c}0.144 \\
(0.007)^{* * *}\end{array}$ & $\begin{array}{c}0.138 \\
(0.009)^{* * *}\end{array}$ \\
\hline Unemployed & $\begin{array}{c}0.237 \\
(0.006)^{* * *}\end{array}$ & $\begin{array}{c}0.241 \\
(0.011)^{* * *}\end{array}$ & $\begin{array}{c}0.200 \\
(0.006)^{* * *}\end{array}$ & $\begin{array}{c}0.192 \\
(0.011)^{* * *}\end{array}$ \\
\hline $\begin{array}{l}\text { Number of days in unemployment } \\
\text { in } 1998 / 100\end{array}$ & & $\begin{array}{c}0.010 \\
(0.012)\end{array}$ & & $\begin{array}{c}0.012 \\
(0.011)\end{array}$ \\
\hline Start-up subsidy & & $\begin{array}{c}-0.070 \\
(0.018)^{* * *}\end{array}$ & & $\begin{array}{l}-0.024 \\
(0.017)\end{array}$ \\
\hline Additional controls & No & No & Yes & Yes \\
\hline Number of observations & 13588 & 13588 & 13577 & 13577 \\
\hline
\end{tabular}

Notes: Model (3) and (4) also includes controls for: age, education, place of residence, second-generation immigrant, and industry. Robust standard errors in parentheses. * significant at 10\%; ** significant at 5\%; *** significant at $1 \%$. 
Table 6 Probability of being a solo entrepreneur (solo) in 2002, marginal effects

\begin{tabular}{|c|c|c|c|c|}
\hline & $\begin{array}{c}(1) \\
\operatorname{Pr}(\text { solo })\end{array}$ & $\begin{array}{c}(2) \\
\operatorname{Pr}(\text { solo })\end{array}$ & $\begin{array}{c}\text { (3) } \\
\operatorname{Pr}(\text { solo })\end{array}$ & $\begin{array}{c}\text { (4) } \\
\operatorname{Pr}(\text { solo })\end{array}$ \\
\hline \multicolumn{5}{|l|}{ Labour market status in 1998} \\
\hline Wage-earner & Ref. & & Ref. & \\
\hline $\begin{array}{l}\text { Lower income than predicted } \\
\text { as wage-earner }\end{array}$ & & $\begin{array}{c}0.063 \\
(0.016)^{* * *}\end{array}$ & & $\begin{array}{c}0.047 \\
(0.016)^{* * *}\end{array}$ \\
\hline $\begin{array}{l}\text { Income about as predicted } \\
\text { as wage-earner }\end{array}$ & & Ref. & & Ref. \\
\hline $\begin{array}{l}\text { Higher income than predicted } \\
\text { as wage-earner }\end{array}$ & & $\begin{array}{l}-0.020 \\
(0.019)\end{array}$ & & $\begin{array}{c}-0.052 \\
(0.020)^{* * *}\end{array}$ \\
\hline Inactive & $\begin{array}{c}0.239 \\
(0.010)^{* * *}\end{array}$ & $\begin{array}{c}0.260 \\
(0.014)^{* * * *}\end{array}$ & $\begin{array}{c}0.194 \\
(0.011)^{* * *}\end{array}$ & $\begin{array}{c}0.204 \\
(0.014)^{* * *}\end{array}$ \\
\hline Unemployed & $\begin{array}{c}0.252 \\
(0.010)^{* * *}\end{array}$ & $\begin{array}{c}0.279 \\
(0.017)^{* * *}\end{array}$ & $\begin{array}{c}0.230 \\
(0.010)^{* * *}\end{array}$ & $\begin{array}{c}0.241 \\
(0.018)^{* * *}\end{array}$ \\
\hline $\begin{array}{l}\text { Number of days in unemployment } \\
\text { in } 1998 / 100\end{array}$ & & $\begin{array}{c}0.014 \\
(0.016)\end{array}$ & & $\begin{array}{c}0.013 \\
(0.017)\end{array}$ \\
\hline Start-up subsidy & & $\begin{array}{c}-0.138 \\
(0.025)^{* * *}\end{array}$ & & $\begin{array}{c}-0.086 \\
(0.026)^{* * *}\end{array}$ \\
\hline Additional controls & No & No & Yes & Yes \\
\hline Number of observations & 7947 & 7947 & 7939 & 7939 \\
\hline
\end{tabular}

Notes: Model (3) and (3) also includes controls for: age, education, place of residence, second-generation immigrant, and industry. Robust standard errors in parentheses. * significant at $10 \%$; ** significant at 5\%; *** significant at $1 \%$. 
Table 7 Probability of having exited self-employment before 2002, marginal effects

\begin{tabular}{|c|c|c|c|c|}
\hline & $\begin{array}{c}(1) \\
\operatorname{Pr}(\text { exit) }\end{array}$ & $\begin{array}{c}(2) \\
\operatorname{Pr}(\text { exit) }\end{array}$ & $\begin{array}{c}\text { (3) } \\
\operatorname{Pr}(\text { exit) }\end{array}$ & $\begin{array}{c}(4) \\
\operatorname{Pr}(\text { exit) }\end{array}$ \\
\hline \multicolumn{5}{|l|}{ Labour market status in 1998} \\
\hline Wage-earner & Ref. & & Ref. & \\
\hline $\begin{array}{l}\text { Lower income than predicted } \\
\text { as wage-earner }\end{array}$ & & $\begin{array}{c}0.069 \\
(0.016)^{* * *}\end{array}$ & & $\begin{array}{c}0.063 \\
(0.016)^{* * *}\end{array}$ \\
\hline $\begin{array}{l}\text { Income about as predicted } \\
\text { as wage-earner }\end{array}$ & & Ref. & & Ref. \\
\hline $\begin{array}{l}\text { Higher income than predicted } \\
\text { as wage-earner }\end{array}$ & & $\begin{array}{c}0.061 \\
(0.018)^{* * *}\end{array}$ & & $\begin{array}{c}0.032 \\
(0.018)^{*}\end{array}$ \\
\hline Inactive & $\begin{array}{c}0.062 \\
(0.010)^{* * *}\end{array}$ & $\begin{array}{c}0.114 \\
(0.015)^{* * *}\end{array}$ & $\begin{array}{c}0.073 \\
(0.010)^{* * *}\end{array}$ & $\begin{array}{c}0.114 \\
(0.016)^{* * *}\end{array}$ \\
\hline Unemployed & $\begin{array}{c}0.117 \\
(0.012)^{* * *}\end{array}$ & $\begin{array}{c}0.210 \\
(0.024)^{* * * *}\end{array}$ & $\begin{array}{c}0.121 \\
(0.012)^{* * *}\end{array}$ & $\begin{array}{c}0.193 \\
(0.024)^{* * *}\end{array}$ \\
\hline $\begin{array}{l}\text { Number of days in unemployment } \\
\text { in 1998/100 }\end{array}$ & & $\begin{array}{c}-0.011 \\
(0.010)\end{array}$ & & $\begin{array}{l}-0.006 \\
(0.011)\end{array}$ \\
\hline Start-up subsidy & & $\begin{array}{c}-0.088 \\
(0.017)^{* * *}\end{array}$ & & $\begin{array}{c}-0.077 \\
(0.017)^{* * *}\end{array}$ \\
\hline Additional controls & No & No & Yes & Yes \\
\hline Number of observations & 13434 & 13434 & 13425 & 13425 \\
\hline
\end{tabular}


Table 8 Probability of having exited self-employment before 2002 for different destinations. Coefficients estimated with logit and multinomial logit

\begin{tabular}{|c|c|c|c|}
\hline & \multirow{2}{*}{$\begin{array}{c}\text { LOGIT } \\
\text { (4) } \\
\operatorname{Pr}(\text { exit) } \\
\end{array}$} & \multicolumn{2}{|c|}{$\begin{array}{l}\text { MULTINOMIAL LOGIT } \\
\text { (4) }\end{array}$} \\
\hline & & $\operatorname{Pr}($ wage-earner) & $\operatorname{Pr}$ (other) \\
\hline \multicolumn{4}{|l|}{ Labour market status in 1998} \\
\hline $\begin{array}{l}\text { (1b)Lower income than predicted } \\
\text { as wage-earner }\end{array}$ & $\begin{array}{c}0.259 \\
(0.068)^{* * *}\end{array}$ & $\begin{array}{c}0.073 \\
(0.078)\end{array}$ & $\begin{array}{c}0.664 \\
(0.109)^{* * *}\end{array}$ \\
\hline $\begin{array}{l}\text { (2b)Income about as predicted } \\
\text { as wage-earner }\end{array}$ & Ref. & Ref. & Ref. \\
\hline \multirow{2}{*}{$\begin{array}{l}\text { (3b)Higher income than predicted } \\
\text { as wage-earner }\end{array}$} & 0.132 & 0.155 & 0.089 \\
\hline & $(0.075)^{*}$ & $(0.084)^{*}$ & $(0.127)$ \\
\hline \multirow[t]{2}{*}{ (4b)Inactive } & 0.472 & -0.197 & 1.309 \\
\hline & $(0.065)^{* * *}$ & $(0.079)^{* *}$ & $(0.103)^{* * *}$ \\
\hline \multirow[t]{2}{*}{ (5b)Unemployed } & 0.790 & 0.194 & 1.616 \\
\hline & $(0.100)^{* * *}$ & $(0.125)$ & $(0.136)^{* * *}$ \\
\hline \multirow{2}{*}{$\begin{array}{l}\text { Number of days in unemployment } \\
\text { in } 1998 / 100\end{array}$} & -0.026 & -0.075 & -0.001 \\
\hline & $(0.044)$ & $(0.058)$ & $(0.051)$ \\
\hline \multirow[t]{2}{*}{ Start-up subsidy } & -0.331 & -0.111 & -0.516 \\
\hline & $(0.076)^{* * *}$ & $(0.095)$ & $(0.098)^{* * *}$ \\
\hline \multirow[t]{2}{*}{ Constant } & -0.122 & -0.379 & -1.536 \\
\hline & $(0.101)$ & $(0.120)^{* * *}$ & $(0.142)^{* * *}$ \\
\hline Additional controls & Yes & Yes & Yes \\
\hline Number of observations & 13425 & 13434 & 13434 \\
\hline
\end{tabular}

